\title{
KANDUNGAN FENOLIK DAN FLAVONOID TOTAL PADA EKSTRAK DAUN SRIKAYA (Annona squamosa L.) TERFERMENTASI
}

\section{TOTAL PHENOLIC and FLAVONOID CONTENTS of SRIKAYA (Annona squamosa L.) LEAF FERMENTED EXTRACTS}

\author{
Dyah Aryantini ${ }^{1}$, Fita Sari ${ }^{2}$, Citra Rahma Wijayanti ${ }^{3}$ \\ 1,2,3 Laboratorium Biologi Farmasi, Fakultas Farmasi, Institut Ilmu Kesehatan Bhakti Wiyata, Kediri
}

Naskah diterima tanggal 7 Agustus 2020

\begin{abstract}
Srikaya leaves contain phenolic and flavonoid compounds can be used as antioxidants, antidiabetic, hepatoprotective, antitumor. Fermentation cause changes in chemical compounds that affect plant bioactivity. The aim of this study was to determine total phenolic and flavonoid content of srikaya leaf extract and it fermented with probiotic for 24, 48 and 72 hours. Extraction by maceration method using $70 \%$ ethanol. Determination of total phenolic and flavonoid content by UVVis spectrophotometry. Total phenolic content was determined by gallic acid standard concentrations of series 40,55, 70, 85, $100 \mathrm{ppm}$, total flavonoids content by quercetin concentrations of $40,65,90,115,140 \mathrm{ppm}$. Total phenolic content of extract is $4.028 \pm 0.064 \mathrm{mgGAE} / \mathrm{g}$, while the fermented extracts at 24, 48, 72 hours are $8.817 \pm 0.079 \mathrm{mgGAE} / \mathrm{g} ; 7.391 \pm 0.018 \mathrm{mgGAE} / \mathrm{g} ; 5.997 \pm 0.078 \mathrm{mg} \mathrm{GAE} / \mathrm{g}$. Total flavonoid content of extract $3.861 \pm 0.041 \mathrm{mgQE} / \mathrm{g}$, the fermented extract at 24,48 and 72 hours are $17.022 \pm 0.392 \mathrm{mgQE} / \mathrm{g} ; 11,691 \pm 0.268 \mathrm{mgQE} / \mathrm{g} ; 9,227$ $\pm 0.243 \mathrm{mgQE} / \mathrm{g}$. The conclusions are the process and duration of fermentation affecting the content of total phenolic and flavonoids in srikaya leaf extract and fermented extract.
\end{abstract}

Keywords: srikaya, fermented extract, phenolic content, duration of ferementation

\begin{abstract}
ABSTRAK
Daun srikaya mengandung senyawa fenolik dan flavonoid yang dapat digunakan sebagai antioksidan, antidiabetik, hepatoprotektif, antitumor. Fermentasi menyebabkan perubahan senyawa kimia sehingga mempengaruhi bioaktivitas tanaman. Tujuan dari penelitian ini adalah untuk mengetahui kandungan total fenolik dan flavonoid pada ekstrak daun srikaya dan ekstrak daun srikaya terfermentasi probiotik dengan lama fermentasi 24, 48 dan 72 jam. Ekstraksi daun srikaya dengan metode maserasi menggunakan pelarut etanol $70 \%$. Penetapan kandungan total fenolik dan flavonoid menggunakan spektrofotometri UV-Vis. Kandungan total fenolik ditetapkan dengan asam galat konsentrasi baku seri 40 , $55,70,85,100 \mathrm{ppm}$, penentuan kandungan total flavonoid dengan kuersetin konsentrasi 40,65, 90, 115, $140 \mathrm{ppm}$. Hasil penetapan kandungan total fenolik ekstrak adalah 4,028 $\pm 0,064 \mathrm{mgGAE} / \mathrm{g}$, sedangkan kandungannya pada ekstrak terfermentasi berturut-turut pada $24,48,72$ jam yaitu $8,817 \pm 0,079 ; 7,391 \pm 0,018$

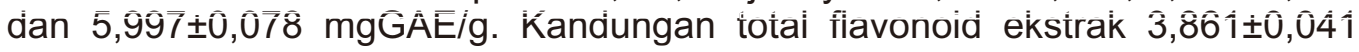
$\mathrm{mgQE} / \mathrm{g}$, pada ekstrak terfermentasi jam ke-24, 48, 72 berturut-turut yaitu $17,022 \pm 0,392 ; 11,691 \pm 0,268$ dan 9,227 $\pm 0,243 \mathrm{mgQE} / \mathrm{g}$. Kesimpulan yang diperoleh adalah proses dan lama fermentasi mempengaruhi kandungan total fenolik dan flavonoid pada ekstrak daun srikaya dan ekstrak daun srikaya terfermentasi.
\end{abstract}

Kata Kunci : srikaya, ekstrak terfermentasi, total fenolik, lama fermentasi 


\section{PENDAHULUAN}

Senyawa fenolik merupakan senyawa bioaktif yang memiliki peran besar pada manusia diantaranya dalam pencegahan dan pengobatan penyakit degeneratif, kanker, penuaan dini dan ganguan sistem imun tubuh (Apsari, 2011). Sedangkan hampir semua tumbuhan di alam termasuk bagian buah, akar, daun dan kulit batang mengandung senyawa flavonoid yang tak kalah pentingnya dengan senyawa fenolik dalam memberikan efek farmakologi pada manusia (Ahmad, 2015)

Tanaman Annona squamosa L. atau yang sering disebut srikaya adalah salah satu contoh tanaman yang mengandung senyawa fenolik dan flavonoid. Senyawa fenolik dan flavonoid adalah senyawa yang memiliki gugus polyol dan memiliki banyak aktivitas farmakologi yang bermanfaat bagi kesehatan. Daun srikaya mengandung senyawa fenolik dan flavonoid yang dapat digunakan sebagai antioksidan, antidiabetik, hepatoprotektif, aktivitas antitumor, dan lain sebagainya (Purwita, 2013). Biji srikaya bermanfaat untuk mengatasi gangguan pencernaan, cacingan, mematikan kutu kepala, dan serangga. Buah muda dapat digunakan untuk mengatasi diare, disentri akut, dan gangguan pencernaan. Bagian akar bermanfaat mengatasi sembelit, disentri akut, depresi mental, dan nyeri tulang punggung. Kulit kayu digunakan untuk mengatasi diare, disentri, dan luka berdarah (Soedarso, 2012).

Penelitian sebelumnya, Adetuyi dan Ibrahim (2014) meneliti tentang pengaruh waktu fermentasi dengan interval waktu inkubasi 0,24 , 72 , dan 120 jam terhadap kandungan total fenolik, flavonoid, vitamin C serta aktivitas antioksidan pada biji okra. Hasil penelitian menunjukkan bahwa biji okra yang difermentasi memiliki jumlah total kandungan fenolik lebih besar dibandingkan dengan yang tidak difermentasi. Fermentasi pada jam ke-24 memberikan total kandungan fenolik paling besar. Penelitian lainnya, Nazarni, dkk (2016) meneliti tentang pengaruh fermentasi terhadap kandungan total fenolik, flavonoid, dan tanin serta hubungannya dengan aktivitas antibakteri pada tanaman jaruk tiguran. Hasil yang didapatkan adalah fermentasi memberikan jumlah kandungan total fenolik, flavonoid, dan tanin lebih banyak dibandingkan tanpa fermentasi.

Berdasarkan penelitian yang dilakukan Dini Rizkiawati (2017) tentang ekstrak daun srikaya terfermentasi aktif menghambat Staphylococcus aureus. Aktivitas tersebut lebih tinggi dibandingkan dengan ekstrak daun srikaya yang tidak difermentasi. Penelitian ini terfokus pada kandungan senyawa flavonoid total dan senyawa fenolik total pada ekstrak daun srikaya terfermentasi probiotik.

\section{METODE PENELITIAN}

Alat

Alat-alat yang digunakan dalam penelitian ini adalah spektrofotometer UV Visible (Shimadzu), Autoklaf (Yazumi), Inkubator Mikrobiologi(Memmert), Mikropipet (Dragonlab), Lampu UV (Camag)

\section{Bahan}

Etanol $70 \%$ teknis (Bratachem), Kloroform teknis (Bratachem), Asam Galat (Merck), Kuersetin (Merck), reagen Folin Ciocalteu (Merck), $\mathrm{AlCl}_{3}$ (Merck), media MRSA dan MRSB (Oxoid), media susu sapi murni, sumber probiotik berupa yogurt plain (Biokul). Sebagai bahan penelitian utama adalah daun srikaya yang diperoleh di desa Bandar Lor, Kecamatan Mojoroto, Kota Kediri. Daun dikumpulkan siang hari saat terik panas matahari terhadap daun pada urutan ketiga sampai lima pada setiap rantingnya.

\section{Metode}

\section{Pembuatan Ekstrak}

Determinasi daun srikaya dilakukan di Materia Medika Batu Malang. Metode ekstraksi terhadap simplisia dilakukan secara maserasi. Pelarut yang digunakan dalam ekstraksi adalah etanol $70 \%$. Sebanyak 1000 gram serbuk simplisia direndam dalam 10 Liter etanol $70 \%$ selama 3 hari dalam bejana tertutup rapat dengan pengadukan berulang.

2. Skrining Fitokimia Secara Kualitatif

a. Terhadap senyawa fenolik dan flavonoid

Skrining fitokimia fenolik dilakukan dengan cara $1 \mathrm{ml}$ ekstrak dimasukkan ke tabung reaksi lalu ditambahkan $\mathrm{FeCl}_{3}$ 1\% 3-5 tetes. Hasil positif senyawa fenolik memberikan warna hijau hingga biru hitam (Hanani, 2015).

Skrining fitokimia flavonoid dilakukan dengan cara $1 \mathrm{ml}$ ekstrak dimasukkan ke tabung reaksi lalu ditambahkan serbuk Mg dan beberapa tetes $\mathrm{HCl}$ pekat. Warna jingga sampai merah menandakan positif flavonoid (Faskalia, 2014).

b. Secara kromatografi lapis tipis (KLT).

Metode KLT dengan cara menotolkan ekstrak kental pada fase diam silica gel GF254 yang telah diaktivasi. Untuk senyawa fenolik digunakan fase gerak asam asetat:kloroform (1:9 $\mathrm{v} / \mathrm{v})$ ) dan dilanjutkan dengan penegasan reaksi semprot mengunakan reagen $\mathrm{FeCl} 3$.

Untuk mendeteksi keberadaan senyawa flavonoid digunakan fase gerak n-Butanol:asam asetat;air $(4: 1: 5 \mathrm{v} / \mathrm{v})$ dan dilanjutkan dengan reaksi penegasan uap ammonia.

3. Identifikasi Mikroskopis Bakteri Asam Laktat.

Alat-alat yang digunakan dalam proses fermentasi disterilkan terlebih dahulu dengan sterilisasi basah mengunakan autoklaf pada suhu $120^{\circ} \mathrm{C}$ selama 15 menit dan sterilisasi kering pada oven suhu $110^{\circ} \mathrm{C}$ 
Fermentasi pada penelitian ini memanfaatkan aktivitas bakteri asam laktat yaitu Lactobacillus, Streptococcus, dan Bifidobacterium yang terdapat pada sediaan yoghurt Biokul Plain. Identifikasi mikroskopis pada sediaan yoghurt Biokul Plain untuk mengetahui bentuk bakteri melalui pewarnaan gram. Sebanyak $1 \mathrm{ml}$ dimasukkan ke tabung reaksi yang berisi $10 \mathrm{ml}$ MRSB (De Mann Rogosa Sharpe Broth) lalu diinkubasi selama 24 jam suhu $37^{\circ} \mathrm{C}$. Bakteri hasil inkubasi diambil dengan menggunakan ose bulat sebanyak 1 ose lalu diinokulasi ke dalam MRSA (De Mann Rogosa Sharpe Agar) pada cawan petri membentuk zig zag. Cawan petri diinkubasi suhu $37^{\circ} \mathrm{C}$ selama 48 jam lalu dilakukan pengamatan.

\section{Fermentasi Ekstrak}

Fermentasi ekstrak dibuat dengan cara menyiapkan 3 kelompok perlakuan yakni 24 jam, 48 jam dan 72 jam dengan masing-masing 3 replikasi menggunakan media susu sapi murni yang lebih dahulu dipasteurisasi dengan pemanasan $85^{\circ} \mathrm{C}$ selama 10 menit kemudian didiamkan hingga suhu turun mencapai $42-45^{\circ} \mathrm{C}$ kemudian ditambahkan $10 \% \mathrm{v} / \mathrm{v}$ yogurt yang berlaku sebagai starter pada setiap tabung perlakuan. Setiap tabung ditambahkan ekstrak daun srikaya kemudian diamati setiap periode jam ke 24,48 dan 72 pada suhu $37^{\circ} \mathrm{C}$.

5. Uji pH Ekstrak Terfermentasi

Salah satu keberhasilan suatu proses fermentasi ditentukan oleh derajat keasaman $(\mathrm{pH})$. Untuk mengetahui $\mathrm{pH}$ ekstrak terfermentasi maka perlu dilakukan pengukuran $\mathrm{pH}$ sebelum dan sesudah diinkubasi.

6. Penetapan Kandungan Senyawa Total Secara Spektrofotometri

a. Kandungan senyawa fenolik total

1) Penentuan $\lambda_{\max }$

2) Penentuan operating time

3) Pembuatan kurva standar

Larutan baku induk asam galat 1000 ppm dibuat variasi baku seri 40, 55, 70, 85, 100 ppm. Diambil baku seri masing-masing $1 \mathrm{ml}$ dan ditambahkan $0,5 \mathrm{ml}$ reagen Folin-Ciocalteu $10 \%$, selanjutnya ditambahkan $4 \mathrm{ml} \mathrm{Na}_{2} \mathrm{CO}_{3} 1 \mathrm{M}$. Didiamkan selama operating time dan dibaca absorbansi pada panjang gelombang maksimum (Sari, 2017).

4) Penetapan kandungan senyawa total

Penetapan kadar fenolik total dilakukan dengan menggunakan pereaksi Folin-Ciocalteu. Sebanyak $1 \mathrm{ml}$ larutan ekstrak ditambah 0,5 ml reagen Folin-Ciocalteu dan $4 \mathrm{ml} \mathrm{Na}_{2} \mathrm{CO}_{3} 1 \mathrm{M}$ lalu diinkubasi selama operating time kemudian diukur absorbansi pada panjang gelombang maksimum (Anwar, 2016)

b. Kandungan senyawa flavonoid total

1) Penentuan $\lambda_{\max }$

2) Penentuan Operating Time

\section{3) Penentuan kurva baku standar}

Larutan baku dibuat dengan cara $10 \mathrm{mg}$ kuersetin dilarutkan dengan etanol ad $10 \mathrm{ml}$ sehingga diperoleh konsentrasi 1000 ppm. Selanjutnya dibuat baku seri dengan variasi konsentrasi 40, 65, 90, 115, dan 140 ppm lalu masing-masing baku seri diambil $1 \mathrm{ml}$ dan direaksikan dengan $1 \mathrm{ml} \mathrm{AlCl} 310 \%$, kemudian ditambahkan $8 \mathrm{ml}$ asam asetat $5 \%$ dan didiamkan selama operating time lalu diukur absorbanci pada panjang gelombang maksimum. Kurva standar diperoleh dari hubungan konsentrasi kuersetin (ppm) dengan absorbansi (Ipandi, 2016).

4) Penetapan Kandungan Senyawa Total

Penetapan kadar flavonoid total dilakukan dengan metode Chang et al (2002). Larutan ekstrak diambil $1 \mathrm{ml}$ lalu dimasukkan ke tabung, ditambahkan $\mathrm{AlCl}_{3} 10 \%$ dan $8 \mathrm{ml}$ asam asetat $5 \%$. Larutan diinkubasi selama operating time pada suhu ruang kemudian dilakukan pembacaan absorbansi pada panjang gelombang maksimum (Bakti, 2017)

\section{Analisis Data}

Data dianalisa secara statistik dengan SPSS Windows 8. Varian yang terdistribusi normal dan homogen dianalisa dengan ANOVA One Way dan dilanjutkan dengan metode Post Hoc dengan tingkat kepercayaan $<0,05$ untuk mendapatkan kelompok yang memiliki perbedaan bermakna.

\section{HASIL DAN PEMBAHASAN}

1. Ekstraksi Daun Srikaya

Metode maserasi yang digunakan dalam penelitian ini diharapkan dapat mencegah kerusakan senyawa fenolik dan flavonoid akibat pemanasan saat ekstraksi (Yuda, 2017). Ekstrak daun srikaya diperoleh sebanyak 201,364 gram dengan rendemen sebesar $20,14 \%$

2. Skrining Fitokimia

a. Terhadap senyawa fenolik dan flavonoid

Menunjukkan hasil positif adanya senyawa fenolik dengan warna hijau hingga biru kehitaman (Hanani, 2015). Hasil positif adanya senyawa flavonoid juga ditandai dengan adanya warna jingga hingga merah (Faskalia, 2014).

\section{b. Secara KLT}

Bercak yang terjadi pada setiap plat dideteksi dibawah lampu UV 254 dan 366 nm. Hasil KLT senyawa fenolik di bawah lampu UV 366 disajikan dalam Gambar 1 menunjukkan senyawa berwarna biru (berpendar) di bawah lampu UV $366 \mathrm{~nm}$ pada $\mathrm{Rf} 35,40,79,85$ dan 90. Dengan penampak bercak $\mathrm{FeCl} 31 \%$ bercak tersebut menunjukkan warna coklat. Menurut Hanani (2017) bercak warna biru dengan Rf 35 diduga senyawa fenolik.

Hasil pengamatan KLT senyawa 


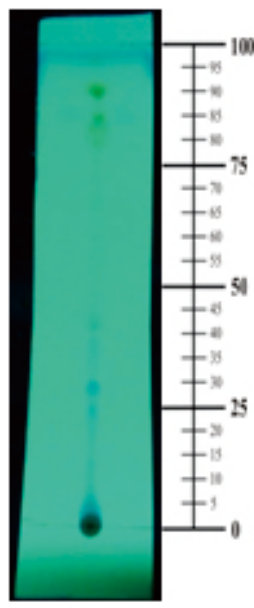

(a)

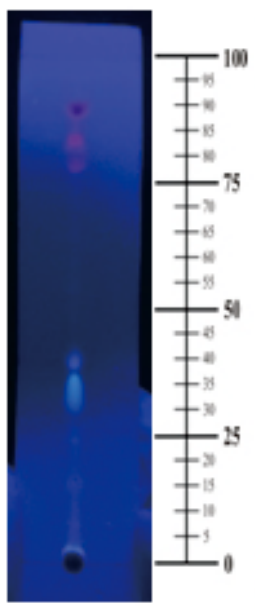

(b)

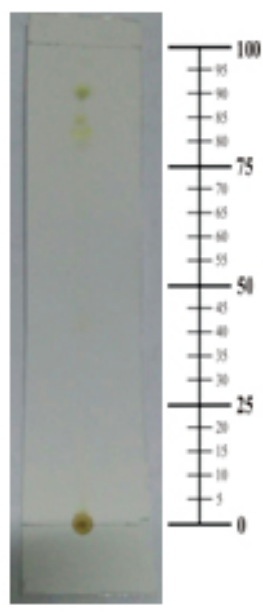

(c)
Keterangan :
(a) : lampu UV $254 \mathrm{~nm}$
(b) : lampu UV $366 \mathrm{~nm}$
(c) : visibel

\section{Eluen}

Fase diam asam asetat : kloroform (1:9)

Penampak bercak $: \mathrm{FeCl}_{3} 1 \%$

\section{Gambar 1. Uji KLT Fenolik Ekstrak Daun Srikaya}

flavonoid ditunjukkan pada Gambar 2 dengan noda hitam yang meredam fluoresensi pada Rf 60 , dengan reaksi penampak bercak uap ammonia memperlihatkan bahwa noda berwarna

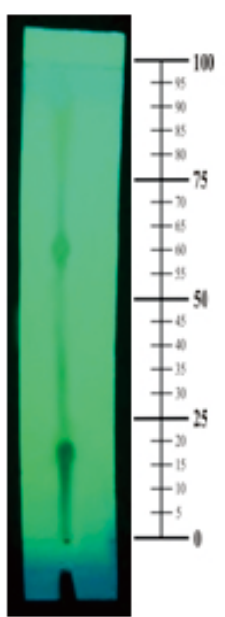

(a)

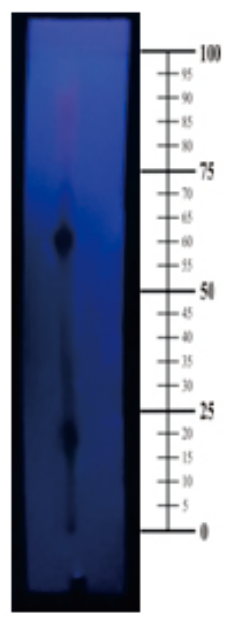

(b)

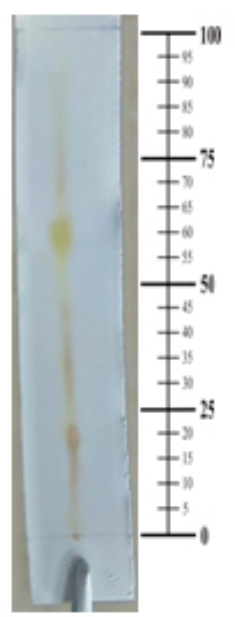

(c)
Keterangan :
(a) : lampu UV $254 \mathrm{~nm}$
(b) : lampu UV $366 \mathrm{~nm}$
(c) : visibel (c)

Eluen $\quad$ : n-butanol:asam asetat:air (4:1:5)

Fase diam : silika gel F254

Penampak bercak : uap amonia

\section{Gambar 2. Uji KLT Flavonoid Ekstrak Daun Srikaya}

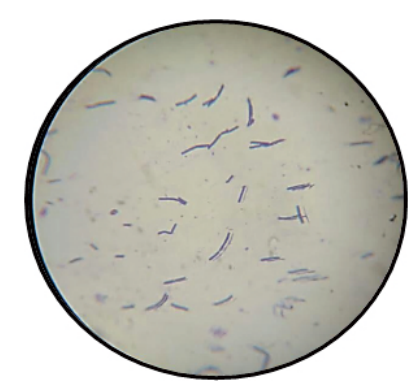

\section{Gambar 3. Pengamatan Mikroskopis BAL dengan Perbesaran 100x}

kuning (Rizkiawati, 2017).

Hasil pengujian menunjukkan bahwa ekstrak daun srikaya positif mengandung senyawa fenolik dan flavonoid baik secara kualitatif dengan uji warna maupun KLT.

3. Identifikasi Mikroskopis Bakteri Asam Laktat

Hasil pewarnaan pada Gambar 3 menunjukkan bahwa jenis bakteri yang terdapat dalam yogurt Biokul Plain adalah bakteri asam laktat dengan warna ungu, tergolong gram positif dan berbentuk basil. Sel bakteri Gram Positif terlihat berwarna ungu karena dapat membentuk ikatan komplek dengan reagen gentian violet (Ismail dkk, 2017).

\section{Fermentasi Ekstrak}

Kombinasi probiotik dalam yogurt sebagai starter fermentasi menyebabkan bakteri memiliki fase eksponensial dan stasioner yang lebih panjang, sehingga diharapkan ekstrak terfermentasi dalam waktu yang cukup panjang dalam periode 24 sampai 72 jam. Dengan adanya kombinasi bakteri asam laktat meningkatkan pertumbuhan biomassa dan mempercepat proses fermentasi (Kamara dkk, 2016)

5. Uji pH Pada Ekstrak Terfermentasi

Hasil pengukuran $\mathrm{pH}$ pada ekstrak kental adalah 5 , sedangkan pada ekstrak terfermentasi 24 jam $\mathrm{pH} 3$, ekstrak fermentasi 48 jam dan 72 jam keduanya dengan $\mathrm{pH} 2$. Penurunan $\mathrm{pH}$ ekstrak akibat proses fermentasi dan terjadi akumulasi asam laktat yang menghasilkan $\mathrm{CH}_{3} \mathrm{CHOHCOO}$ dan $\mathrm{H}^{+}$, sehingga ion $\mathrm{H}^{+}$yang dibebaskan semakin tinggi.. Fermentasi 48 jam dan 72 jam memberikan nilai $\mathrm{pH}$ yang tidak berbeda signifikan karena berkurangnya nutrisi yang dibutuhkan bakteri, sehingga mengakibatkan menurunnya pembentukan asam laktat selama fermentasi.

\section{Penetapan Kandungan Senyawa Total Secara Spektrofotometri \\ a. Penetapan kandungan senyawa fenolik total \\ Penetapan kandungan senyawa} menggunakan konsentrasi asam galat $40 \mathrm{ppm}$, 55 ppm, 70 ppm, 85 ppm dan 100 ppm. Waktu operasional yang didapatkan adalah 30 menit 


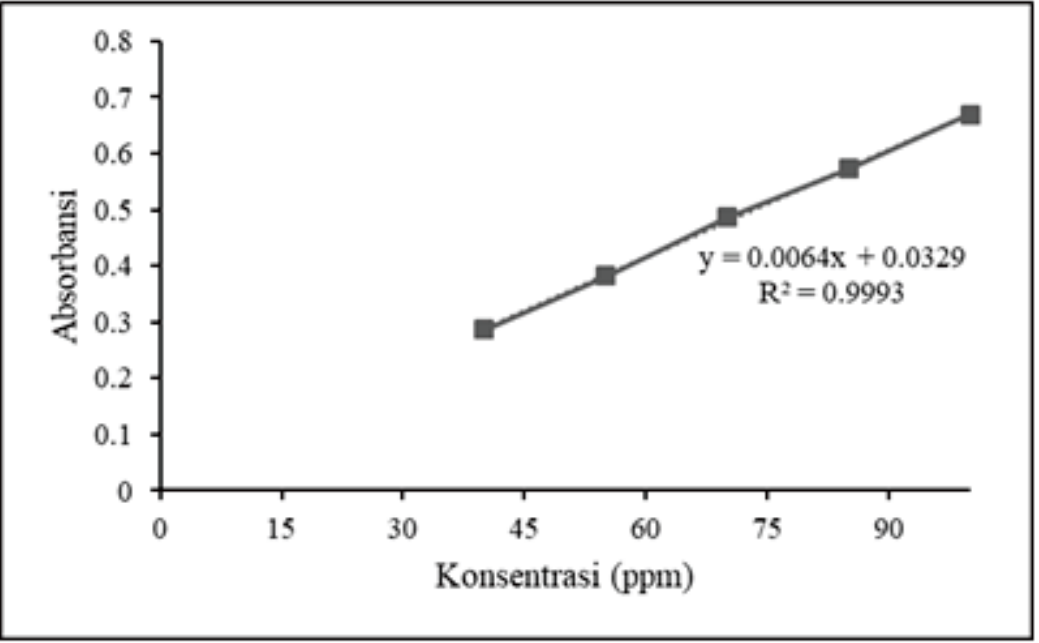

Gambar 4. Grafik Hubungan Konsentrasi Asam Galat vs Absorbansi Senyawa Fenolik

dengan panjang gelombang maksimum $745 \mathrm{~nm}$. Penyajian Gambar 4 menunjukkan hubungan konsentrasi asam galat dengan absorbansi. Nilai r yang mendekati 1 menunjukkan kurva kalibrasi linier dan terdapat hubungan antara konsentrasi larutan standar dengan nilai serapan (Sari, 2017). Persamaan regresi yang didapatkan digunakan untuk penetapan kadar fenolik total sampel. Hasil penetapan kadar fenolik total ekstrak kental dan ekstrak fermentasi $(24,48,72$ jam) berturut-turut yaitu $4,028 \pm 0,064 ; 8,817 \pm 0,078 ; 7,391 \pm 0,018$; $5,997 \pm 0,078 \mathrm{mgGAE} / \mathrm{g}$. Peningkatan kadar senyawa fenolik total dapat disebabkan adanya reaksi enzimatik dalam substrat yang mengeluarkan lebih banyak senyawa fenolik sebagai produk akhir. (Ibrahim, 2014). Adanya lingkungan asam yang disebabkan oleh asam laktat maupun asam organic lainnya dalam ekstrak terfermentasi memicu pembentukan senyawa fenol melalui asam hidroksi sinamat dan asam ferulat (Parhusip, 2019).

b. Penetapan kandungan senyawa flavonoid total
Kurva baku standar dibuat dengan variasi baku seri kuersetin 40 ppm, 65 ppm, 90 ppm, 115 ppm, 140 ppm. Nilai absorbansi terbesar pada panjang gelombang $410 \mathrm{~nm}$. Penentuan operating time (OT) dilakukan tiap 5 menit selama 60 menit dan didapatkan hasil OT pada waktu 15 menit menunjukkan nilai absorbansi yang stabil, berarti reaksi telah berjalan sempurna.

Pada Gambar 5 menunjukkan korelasi antara konsentrasi kuersetin dengan absorbansinya. Hasil penetapan kandungan flavonoid total ekstrak kental dan ekstrak fermentasi $(24,48,72$ jam) berturut-turut yaitu $3,861 \pm 0,04 ; 17,022 \pm 0,392 ; 11,691 \pm 0,268$; $9,227 \pm 0,243 \mathrm{mgQE} / \mathrm{g}$. Hasil tersebut menunjukkan bahwa kelompok ekstrak fermentasi memiliki kadar flavonoid total lebih tinggi dibandingkan kelompak ekstrak kental tanpa fermentasi, Hasil tersebut membuktikan bahwa proses fermentasi dapat meningkatkan kadar flavonoid total ekstrak daun srikaya (Annona squamosa L.). Ada kemungkinan besar bahwa fermentasi laktat melibatkan reaksi

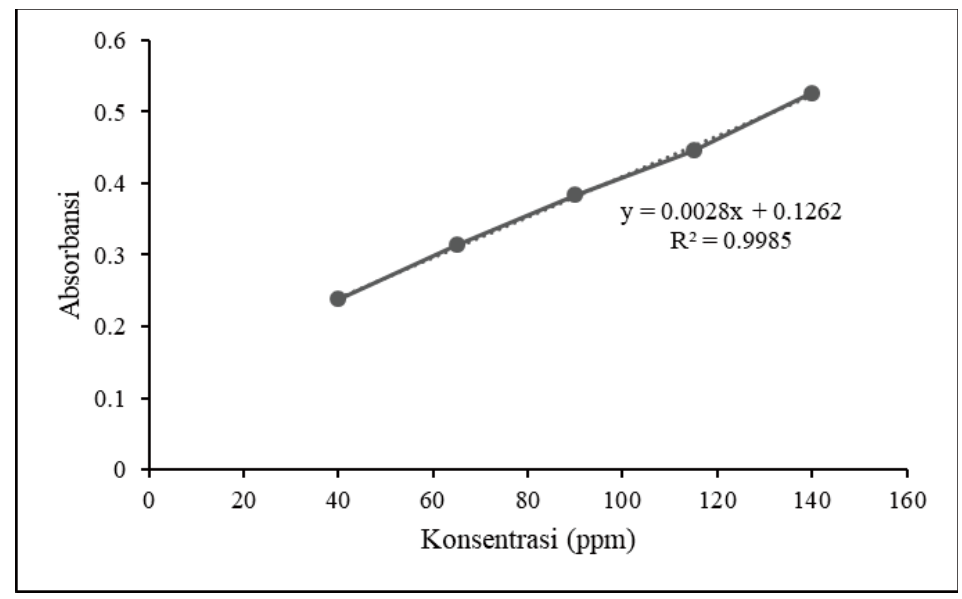

Gambar 5. Grafik Hubungan Konsentrasi Kuersetin vs Absorbansi Senyawa Flavonoid 


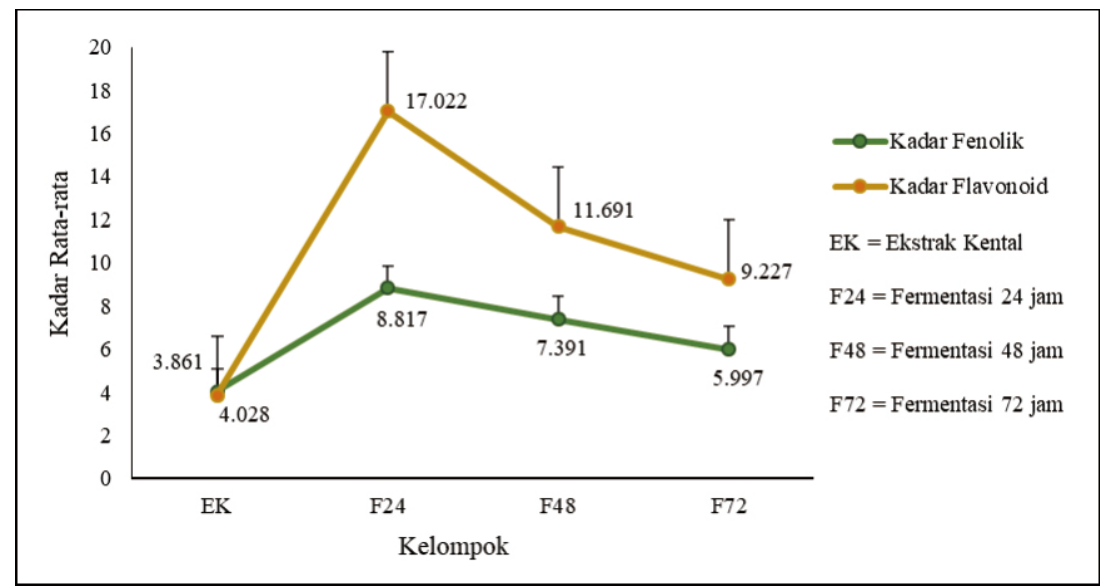

\section{Gambar 6. Grafik Kandungan Senyawa Fenolik Total dan Flavonoid Total Ekstrak Terfermentasi Daun Srikaya}

enzimatik yang dapat memodifikasi senyawa bioaktif substrat, diantaranya adalah menjadi bentuk bebas seperti alkaloid, fenolik dan flavonoid (Ibrahim, 2014).

Penetapan kandungan senyawa fenolik dan flavonoid total ekstrak daun srikaya memberikan hasil bahwa kadar total senyawa pada kelompok ekstrak fermentasi lebih tinggi dibandingkan kelompok ekstrak kental tanpa fermentasi (disajikan dalam gambar 6). Hal ini membuktikan bahwa fermentasi ekstrak dapat meningkatkan kadar total fenolik dan flavonoid pada ekstrak. Kelompok ekstrak fermentasi diperoleh kadar total tertinggi senyawa fenolik dan flavonoid pada periode fermentasi 24 jam.

Berdasarkan analisa data secara statistik dengan uji one-way ANOVA kemudian dilanjutkan dengan uji post hoc menunjukkan ada perbedaan bermakna pada kadar total senyawa fenolik dan flavonoid kelompok ekstrak kental dibandingkan terhadap ekstrak yang terfermentasi dengan tingkat kepercayaan kepercayaan $<0,05$. Hal ini menggambarkan bahwa proses fermentasi mempengaruhi kadar senyawa fenolik dan flavonoid dalam ekstrak.

\section{KESIMPULAN}

Ekstrak daun srikaya terfermentasi terbukti meningkatkan kandungan senyawa fenolik total dan flavonoid total secara spektrofotometri UV Visible. Dapat disimpulkan bahwa lama fermentasi selama 24 jam menunjukkan peningkatan kadar senyawa fenolik dan flavonoid total tertinggi dibandingkan dengan kelompok ekstrak kental, ekstrak terfermentasi 48 jam dan 72 jam. Peningkatan periode fermentasi menyebabkan penurunan kadar total fenolik dan flavonoid. Perlu dilakukan optimasi waktu fermentasi untuk mengetahui kandungan optimum senyawa fenolik dan flavonoid. Dari simpulan tersebut dapat menjadi dasar penelitian jangka panjang dalam formulasi minuman yogurt yang mengandung ekstrak terfermentasi selama 24 jam dari daun srikaya dengan kandungan senyawa fenolik dan flavonoid.

\section{DAFTAR PUSTAKA}

Adetuyi, F.O dan Ibrahim, T.A. 2014. Effect of Fermentation Time on the Phenolic, Flavonoid and Vitamin C Contents and Antioxidant Activities of Okra (Abelmoschus esculentus) Seeds. Journal of Nigerian Institute of Food Science and Technology, Vol. 32, No. 2.

Ahmad, Aktsar R, Juwita, S.A.D. Ratulangi, Abdul Malik. 2015. Penetapan Kadar Fenolik dan Flavonoid Total Ekstrak Metanol Buah dan Daun Patikala (Etlingera elatior (Jack) R.M.SM). Jurnal Pharm Sci Res, Vol. 2 No. 1

Anwar, Khoerul, Liling Triyasmono. 2016. Kandungan Total Fenolik, Total Flavonoid, dan Aktivitas Antioksidan Ekstrak Etanol Buah Mengkudu (Morinda citrifolia L.). Jurnal Pharmascience, Vol. 3(1), 83-92.

Apsari, Pramudita Dwi., \& Susanti, H. 2011. Penetapan kadar fenolik total ekstrak metanol kelopak bunga rosella merah (Hibiscus sabdariffa Linn) dengan variasi tempat tumbuh secara spektrofotometri. Jurnal IImiah Kefarmasian, 2(1), 73-80.

Bakti, A. A, Liling Triyasmono, Muhammad I.R. 2017. Penentuan Kadar Flavonoid Total dan Uji Antioksidan Ekstrak Etanol Daun Kasturi (Mangifera casturi Kosterm.) dengan Metode DPPH. Jurnal Pharmascience. Vol.4(2).

Faskalia, M.H. Wibowo. 2014. Skrining Fitokimia, Uji Aktivitas, Antioksidan dan Uji Sitotoksik Ekstrak Metanol pada Akar dan Kulit Batang Soma (Ploiarium 
Alternifolium). Jurnal Kimia. Vol. 3 (3), hal. 1-6.

Hanani, Endang. 2015. Analisis Fitokimia. Jakarta: Penerbit EGC.

Ibrahim, N.A., Mustafa S, Ismail A. 2014. Effect of lactic fermentation on the antioxidant capacity of Malaysian herbal. International Food Research Journal. Vol 21(4), hal. 1483-1488.

Ipandi, Irvan, Liling Triyasmono, dan Budi Prayitno. 2016. Penentuan Kadar Flavonoid Total dan Aktivitas Antioksidan Ekstrak Etanol Daun Kajajahi (Leucosyke c a pitellata Wedd.) Jurnal Pharmascience. Vol. 3 (2).

Ismail, Y.S, Yulvizar, C, dan Putriani. 2017. Isolasi, Karakterisasi dan Uji Aktivitas Antimikroba Bakteri Asam Laktat dari Fermentasi Biji Kakao (Theobroma cacao L.). Jurnal Bioleuser, Vol. 1(2).

Kamara, D.S, dkk. 2016. Pembuatan dan Aktivitas Antibakteri Yogurt Hasil Fermentasi Tiga Bakteri (Lactobacillus bulgaricus, Streptococcus thermophiles, Lactobacillus acidophilus). Jurnal AlKimia, Vol. 4 (2).

Parhusip, Adolf J.N, Kaywina Junetta Suraja. 2019. Pemanfaatan Bakteri Asam Laktat Pada Minuman Fermentasi Kulit Melinjo Merah Untuk Anti Asam Urat Pada Tikus Wistar. Jurnal Sains dan Teknologi. Vol. $3(1)$, hal $59-70$

Purwita, A.A, Novita K.I, G. Trimulyono. 2013. Penggunaan Ekstrak Daun Srikaya (Annona squamosa) sebagai Pengendali Jamur Fusarium oxysporum secara In Vitro. Jurnal Lentera Bio 2(2): 179-183.

Rizkiawati, Dini. 2017. Aktivitas Antibakteri Ekstrak Daun Srikaya (Annona squamosa L) yang Difermentasi Asam Laktat (Lactobacillus bulgaricus) terhadap Staphylococcus aureus. Skripsi. Institut IImu Kesehatan Bhakti Wiyata Kediri.

Soedarso. 2012. Srikaya Buah Unik Pelindung Serangan Jantung. Surabaya: Penerbit Stomata.

Yuda, Putu Era S.K, Erna Cahyaningsih, N.L. Putu Yuni Winariyanthi. 2017. Skrining Fitokimia dan Analisis Kromatografi Lapis Tipis Ekstrak Tanaman Patikan Kebo (Euphorbia Hirta L.). Jurnal Medicamento. Vol. $3(2)$. 